\title{
Content distibution of rare earth elements + yttrium in Puyango deposit, Ecuador
}

\author{
JOHN MANRIQUE ${ }^{1,2}$ AND JOSÉ E ORTÍZ ${ }^{1}$
}

${ }^{1}$ Universidad Politécnica de Madrid, ETSI Minas y Energía

${ }^{2}$ Universidad Técnica Particular de Loja

Presenting Author: johnmancar@gmail.com

Content distibution of rare earth elements + yttrium in Puyango deposit, Ecuador

$$
\text { 1. 1. manrique }{ }^{1,2^{*}}, \text { J. E. Ortiz }{ }^{2}
$$

${ }^{1}$ Universidad Técnica Particular de Loja, Loja, San Cayetano Alto, PO BOX 11-01-608, Ecuador (*correspondence: jlmanrique@utpl.edu.ec)

${ }^{2}$ Universidad Politécnica de Madrid, ETSI Minas y Energía, C/Ríos Rosas 21, P.O. Box 28003, Madrid, España; joseeugenio.ortiz@upm.es

\section{Introduction}

Rare earth elements (REE) plus yttrium (REY) are known to concentrate in marine phosphorite deposits during their formation, primarily through early diagenetic processes where carbonates are replaced by carbonate fluorapatite [1]. Consequently, this study was initiated to determine the range of REY concentrations hosted by marine black limestones and calcareous black shales of Puyango deposit (V, U, Zn), Ecuador.

\section{Methods, Discussion of Results}

Through the bulk geochemical analysis determined by Industively Coupled Plasma Mass Spectrometry (ActLabs, Ontario, Canada) and mineralogical analysis by X-ray difracction (UTPL, Ecuador), a chemostratigraphic study of the distribution of REY (rare earth elements $+Y$ ) in sedimentary layers of the Puyango deposit was made. The concentration range of REY in the first stratigraphic series is from $54.8 \mathrm{ppm}$ to $229.9 \mathrm{ppm}$, while in the second stratigraphic series the range is from 23.05 $\mathrm{ppm}$ to $434.5 \mathrm{ppm}$. The REY distribution curve in the chemostratigraphic profiles correlate with $\mathrm{P}$ and $\mathrm{U}$.

Mineralogical analysis detected phosphatic minerals fluorapatite and uranosphatite in the samples with the highest content of REY and U, corresponding to black calcareous shales and black limestones, probably formed during sedimentation in an anoxic environment, directly from P-rich aqueous solutions via diagenetic and biochemical processes in the sediments [2,3]. Finally, REY and $U$ are associated with $P$ in the analyzed samples, according to multivariate geostatistical analysis, which indicates that uraniferous phosphates are the REY host must have formed during sedimentation and diagenesis.

[1] Hein, J., et al., Marine phosphorites as potential resources for heavy rare earth elements and yttrium, Minerals. 6 (88) (2016) 1-22. [2] McArthur, M., and Walsh, N. Rare-earth geochemistry of phosphorites. Chem Geol. 47 (3-4) (1984) 191220. [3] Oelkers, E., and Valsami, E. Phosphate mineral reactivity and global sustainability. Elements. 4 (2) (2008) 83-87. 